\title{
Article \\ Self-Healing Products of Cement Pastes with Supplementary Cementitious Materials, Calcium Sulfoaluminate and Crystalline Admixtures
}

\author{
Byoungsun Park ${ }^{1}\left[\right.$ and Young-Cheol Choi ${ }^{2, *}$ (i) \\ 1 Department of Environmental Systems Engineering, Sejong Campus, Korea University, Sejong-si 30019, \\ Korea; bspark0927@korea.ac.kr \\ 2 Department of Civil and Environmental Engineering, Gachon University, Seongnam-si 13120, Korea \\ * Correspondence: zerofe@gachon.ac.kr; Tel.: + 82-31-750-5721; Fax: +82-31-754-2772
}

Citation: Park, B.; Choi, Y.-C. Self-Healing Products of Cement Pastes with Supplementary Cementitious Materials, Calcium Sulfoaluminate and Crystalline Admixtures. Materials 2021, 14, 7201. https://doi.org/10.3390/ma14237201

Academic Editor: Didier Snoeck

Received: 9 October 2021

Accepted: 23 November 2021

Published: 25 November 2021

Publisher's Note: MDPI stays neutral with regard to jurisdictional claims in published maps and institutional affiliations.

Copyright: (c) 2021 by the authors. Licensee MDPI, Basel, Switzerland. This article is an open access article distributed under the terms and conditions of the Creative Commons Attribution (CC BY) license (https:// creativecommons.org/licenses/by/ $4.0 /)$.

\begin{abstract}
The phase composition of self-healing products generated in cracks affects self-healing performance. This study investigated the self-healing products of cementitious materials using supplementary cementitious materials (SCMs), a calcium sulfoaluminate (CSA) expansion agent, and crystalline additives (CAs). Ground-granulated blast-furnace slag (GGBFS), fly ash (FA), and silica fume (SF) were used as SCMs, and anhydrite, $\mathrm{Na}_{2} \mathrm{SO}_{4}, \mathrm{Na}_{2} \mathrm{CO}_{3}$, and $\mathrm{MgCO}_{3}$ were used as crystalline additives (CAs). An artificial crack method was used to collect the self-healing products in the crack of the paste. The phase composition of the self-healing products was analyzed through $X$-ray diffraction (XRD)/Rietveld refinements and thermogravimetry/differential thermogravimetry (TG/DTG) analysis, and their morphology and ion concentration were examined through scanning electron microscopy with energy dispersive spectroscopy (SEM-EDS). From the results, the main compound of self-healing products was found to be calcite. GGBFS and FA decreased the content of portlandite, and the use of CAs led to the formation of alkali sulfate and alkali carbonate. The SEM-EDS analysis results showed that when GGBFS and FA were used, a large proportion of the self-healing products contained C-S-H and C-A-H, and the use of CSA led to the formation of monosulfate and ettringite.
\end{abstract}

Keywords: self-healing concrete; self-healing products; further hydration; phase composition; supplementary cementitious materials

\section{Introduction}

Concrete is the most widely used construction material worldwide, owing to its high compressive strength and low cost; however, it has a high risk of cracking because of hydration, heat and contraction resulting from its relatively low tensile strength [1-4]. Cracks generated in concrete act as passages for moisture and harmful ions, thus degrading the durability of concrete structures [5,6]. Therefore, crack management in concrete is one of the most important aspects in the lifecycle of structures, including construction and maintenance. In terms of crack management, researchers have developed a self-healing concrete technology that can prevent durability reduction by healing cracks in concrete structures owing to the inherent properties of the structures [7-15].

Cementitious materials have a natural characteristic in that cracks of certain widths can be self-healed, in a process called autogenous healing [16-18]. During the autogenous healing of cracks, unreacted cement particles on the crack surface react with water penetrating through the cracks, which are then filled by the products of further hydration $[19,20]$. Therefore, the autogenous healing characteristic of concrete depends on the characteristics of the binder. Recently, many studies have been conducted to improve crack healing performance through autogenous healing using mineral additives [21-31]. 
Tittelboom et al. [21] evaluated the autogenous healing characteristic in terms of the type and mixture proportion of supplementary cementitious materials (SCMs) using water flow tests and isothermal calorimetry. They reported an improvement in the autogenous healing performance after adding ground granulated blast-furnace slag (GGBFS) and fly ash (FA). In addition, they analyzed the healing products in the surface cracks and reported that the precipitation of $\mathrm{CaCO}_{3}$ was the most important factor determining autogenous healing performance. Termkhajornkit et al. [22] generated microcracks by autogenous shrinkage in FA-cement systems and investigated the recovery of physical performance through self-healing. They induced cracks by autogenous shrinkage and measured the compressive strength and chlorine ion diffusion coefficient with respect to the mixture proportion of FA. They noted an increase in the long-term compressive strength and chlorine ion diffusion coefficient with an increasing substitution rate of FA. They reported that FA improved self-healing performance through the pozzolanic reaction of unreacted FA particles. Sisomphon et al. [23] evaluated the autogenous healing performance of cementitious materials mixed with a calcium sulfoaluminate (CSA) expansion agent and crystalline additives (CAs). They evaluated the autogenous healing performance by measuring the crack width reduction due to autogenous healing using an optical microscope. When ordinary Portland cement (OPC) was replaced with $10 \%$ CSA and $1.5 \%$ CAs, $400-\mu \mathrm{m}$ cracks could be healed within 28 days. In particular, they claimed that CSA and CA increased the content of $\mathrm{Ca}^{2+}$ ions in the cracks by diffusing through the crack surface, which promoted the precipitation of $\mathrm{CaCO}_{3}$ and improved the autogenous healing performance. Jaroenratanapirom and Sahamitmongkol [24] evaluated the autogenous healing performance of mortar specimens containing expansion agents and CAs. They reported that CA exhibited a high healing performance for cracks with widths in the range of $0-0.05 \mathrm{~mm}$; however, the performance decreased when increasing the crack width. Roig-Flores et al. [25] and Azarsa et al. [26] investigated the autogenous healing characteristics of concrete containing CAs under various binder and environmental conditions. They experimentally verified that water is indispensable for autogenous healing of concrete containing CAs. Some researchers used superabsorbent polymers (SAPs) to improve autogenous healing performance in cementitious materials [32-35]. They reported that SAPs improved the autogenous healing performance of cementitious materials. However, they focused on the self-sealing properties of SAPs, not on self-healing products themselves.

A literature review shows that most of the existing studies simply evaluated the autogenous healing performance of cement composites and analyzed the self-healing products formed in surface cracks. Huang et al. [36] analyzed self-healing products generated in the cracks of a paste containing GGBFS. They reported that ettringite formed in the cracks by autogenous healing in a paste specimen containing GGBFS. Moreover, they also reported that the self-healing performance of a paste specimen containing GGBFS is higher than that of a normal paste specimen. Li et al. [37] investigated the self-healing products of mortar specimens containing GGBFS and CAs using X-ray diffraction (XRD) and scanning electron microscopy with energy dispersive spectroscopy (SEM-EDS). They reported that the main component of self-healing products is calcite. Park and Choi [38] examined the relationship between self-healing products and the self-healing performance of cementitious materials with GGBFS, CSA, $\mathrm{Na}_{2} \mathrm{SO}_{4}$ and $\mathrm{Al}_{2}\left(\mathrm{SO}_{4}\right)_{3}$. They reported that the phase composition of self-healing products affects the self-healing performance of cementitious materials. However, their research was limited to investigating the effect of GGBFS and some CAs on self-healing properties. Studies of self-healing products generated in the cracks according to various types of SCMs and CAs are particularly lacking. A self-healing concrete containing various types of SCMs and CAs could exhibit improved autogenous healing performance by controlling the self-healing products through further hydration. Hence, it is necessary to investigate the phase composition of self-healing products according to types of SCMs and CAs to predict self-healing performance. 
Accordingly, this study investigated the chemical and phase composition of selfhealing products generated inside the cracks of cementitious materials made using SCMs, a CSA expansion agent, and crystalline additives (CAs). SCMs have a lower reaction rate than OPC, so a greater amount of SCMs remain in the matrix compared to OPC at the same age. For this reason, SCMs can enhance self-healing performance through further hydration. CSA expansion agents can efficiently fill cracks by generating expandable hydrates such as ettringite. In this study, two types of CA were used: CA containing $\mathrm{SO}_{4}{ }^{2-}$ and CA containing $\mathrm{CO}_{3}{ }^{2-}$. CA containing $\mathrm{SO}_{4}{ }^{2-}$ was used to induce the formation of ettringite, and $\mathrm{CA}$ containing $\mathrm{CO}_{3}{ }^{2-}$ was used to induce the formation of calcite. GGBFS, FA, and silica fume (SF) were used as SCMs, and anhydrite, $\mathrm{Na}_{2} \mathrm{SO}_{4}, \mathrm{Na}_{2} \mathrm{CO}_{3}$, and $\mathrm{MgCO}_{3}$ were used as $\mathrm{CAs}$. To analyze the self-healing products generated in the cracks, artificial cracks of a constant width were produced by overlapping slice specimens. Subsequently, the products generated in the artificial cracks were collected. The self-healing products were analyzed using XRD/Rietveld refinements, thermogravimetry/differential thermogravimetry (TG/DTG) analysis, and SEM-EDS.

\section{Materials and Experiments}

\subsection{Materials}

This study used OPC, GGBFS, FA, SF, and CSA as raw materials. Table 1 lists the chemical compositions and physical properties of the raw materials.

Table 1. Chemical compositions and physical properties of raw materials.

\begin{tabular}{cccccc}
\hline & \multicolumn{5}{c}{ Chemical Compositions (wt. \%) } \\
\cline { 2 - 6 } & OPC & GGBFS & FA & SF & CSA \\
\hline $\mathrm{CaO}$ & 63.13 & 45.2 & 5.24 & 0.17 & 3.6 \\
$\mathrm{SiO}_{2}$ & 21.05 & 29.3 & 52.4 & 91.76 & 10.23 \\
$\mathrm{Al}_{2} \mathrm{O}_{3}$ & 4.71 & 13.8 & 24.3 & 0.39 & 0.74 \\
$\mathrm{Fe}_{2} \mathrm{O}_{3}$ & 3.23 & 0.53 & 6.96 & 0.9 & 53.74 \\
$\mathrm{MgO}$ & 3.06 & 4.13 & 1.46 & 1.23 & 0.78 \\
$\mathrm{~K}_{2} \mathrm{O}$ & 1.67 & 0.45 & 1.56 & 0.97 & 0.2 \\
$\mathrm{Na}_{2} \mathrm{O}$ & 0.17 & 0.28 & 0.98 & 0.77 & 0.03 \\
$\mathrm{SO}_{3}$ & 1.05 & 3.59 & 2.15 & 0.41 & 0.48 \\
\hline & & & Physical property & & \\
\hline Density $\left(\mathrm{g} / \mathrm{cm}^{3}\right)$ & 3.14 & 2.9 & 2.15 & 2.35 & 2.73 \\
Blaine fineness $\left(\mathrm{m}^{2} / \mathrm{kg}\right)$ & 376 & 424 & 328 & 17,400 & 708 \\
Mean diameter $(\mu \mathrm{m})$ & 17.47 & 13.16 & 31.96 & 0.15 & 20.45 \\
\hline
\end{tabular}

${ }^{1}$ Specific surface measurements for silica fume taken using the nitrogen adsorption (BET) method.

Figure 1 shows the particle size distributions of the raw materials measured by laser diffraction scattering (LA-960, HORIBA). OPC, GGBFS, and SF exhibited monomodal distributions, whereas CSA and FA both exhibited a bimodal distribution. 


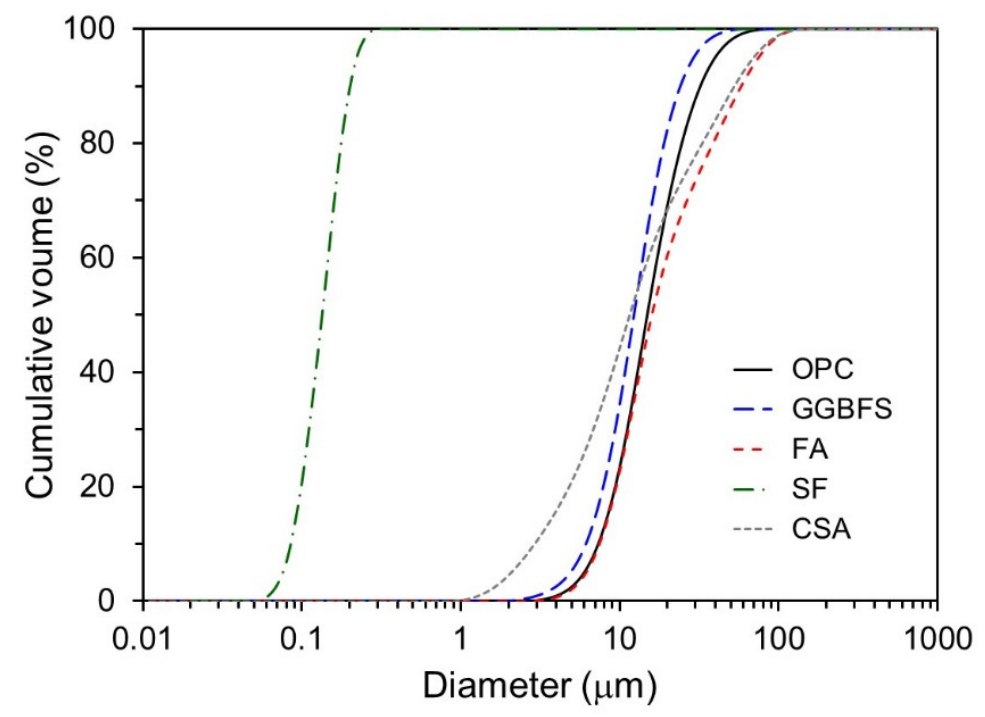

Figure 1. Cumulative volume of particle size distributions of raw materials.

$\mathrm{XRD} /$ Rietveld refinement was performed to calculate the contents of the constituent minerals. Figure 2 shows the XRD patterns of the raw materials. XRD/Rietveld refinement shows that the main constituent minerals in the OPC were $\mathrm{C}_{3} \mathrm{~S}, \mathrm{C}_{2} \mathrm{~S}, \mathrm{C}_{3} \mathrm{~A}$, and $\mathrm{C}_{4} \mathrm{AF}$ with contents of $62.0,16.1,2.5$, and $12.1 \%$, respectively. In addition, the OPC contains $2.6 \%$ gypsum and $4.5 \%$ limestone powder as a mineral admixture. Moreover, the XRD analysis result shows that the GGBFS is largely made of an amorphous phase, accounting for $95 \%$, and the crystalline phase is composed of anhydrite $(2.9 \%)$ and quartz $(2.1 \%)$. The SF does not exhibit any peaks in the XRD patterns, and seems to be mostly made of amorphous phase. The FA is composed of $74.4 \%$ amorphous phase and $25.6 \%$ crystalline phase. The crystalline phase is composed of mullite, quartz, and magnetite, accounting for $13.9,11.3$, and $0.4 \%$, respectively. The CSA is mostly composed of a crystalline phase, and the major constituent minerals are gypsum, calcium sulfoaluminate, and calcium hydroxide, accounting for $48.6,28.0$, and $16.6 \%$, respectively.

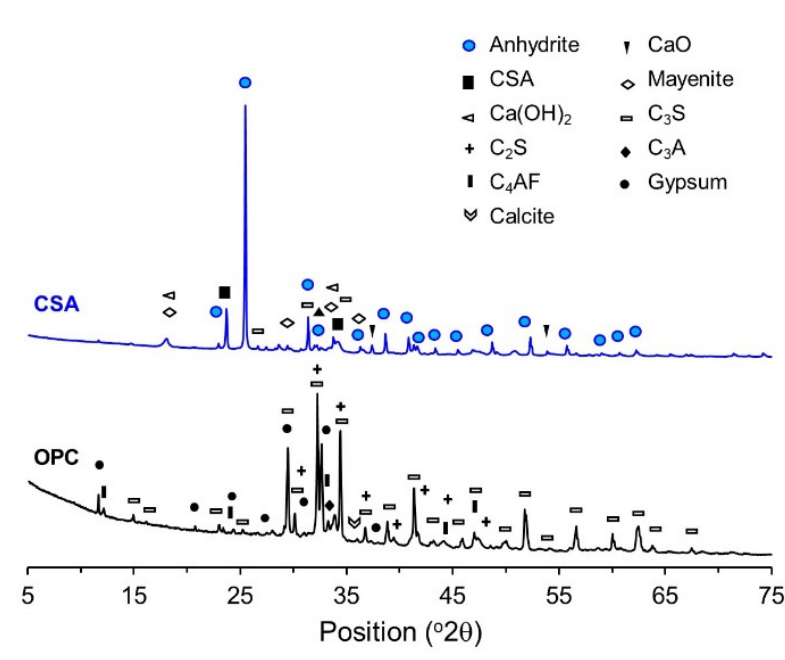

(a)

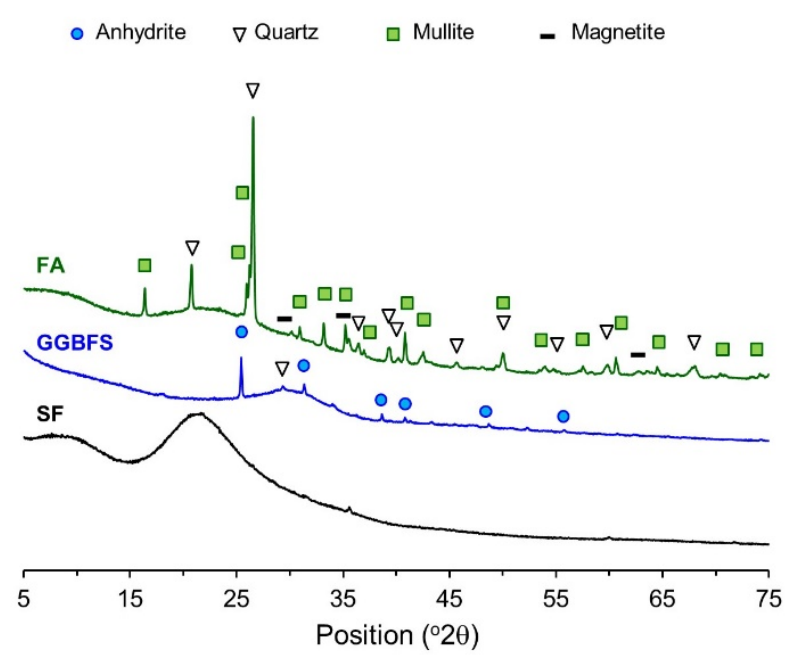

(b)

Figure 2. X-ray diffraction (XRD) pattern of raw materials. (a) Ordinary Portland cement (OPC), Calcium sulfoaluminate (CSA). (b) Fly ash (FA), Ground granulated blast-furnace slag (GGBFS), Silica fume (SF). 


\subsection{Mixture Proportions}

Table 2 lists the mixture proportions of the paste specimens. In this study, the waterto-binder (W/B) ratio was fixed at 0.4. To examine the effects of the type of SCMs on autogenous healing, specimens were fabricated with different types of SCMs and replacement ratios. Furthermore, to improve autogenous healing performance, specimens were fabricated using crystalline additives such as anhydrite, $\mathrm{Na}_{2} \mathrm{SO}_{4}, \mathrm{Na}_{2} \mathrm{CO}_{3}$, and $\mathrm{MgCO}_{3}$.

Table 2. Chemical compositions and physical properties of raw materials.

\begin{tabular}{|c|c|c|c|c|c|c|c|c|c|c|}
\hline & \multirow{2}{*}{ W/B } & \multicolumn{5}{|c|}{ Binder (wt. \%) } & \multicolumn{4}{|c|}{ Crystalline Additive (wt. \%) } \\
\hline & & OPC & GGBFS & FA & SF & CSA & Anhydrite & $\mathrm{Na}_{2} \mathrm{SO}_{4}$ & $\mathrm{Na}_{2} \mathrm{CO}_{3}$ & $\mathrm{MgCO}_{3}$ \\
\hline P100 & 0.4 & 100 & - & - & - & - & - & - & - & - \\
\hline G40 & 0.4 & 60 & 40 & - & - & - & - & - & - & - \\
\hline G60 & 0.4 & 40 & 60 & - & - & - & - & - & - & - \\
\hline G40NS5 & 0.4 & 55 & 40 & - & - & - & - & 5 & - & - \\
\hline SF10 & 0.4 & 90 & - & - & 10 & - & - & - & - & - \\
\hline F35 & 0.4 & 65 & - & 35 & - & - & - & - & - & - \\
\hline F50 & 0.4 & 50 & - & 50 & - & - & - & - & - & - \\
\hline C10 & 0.4 & 90 & - & - & - & 10 & - & - & - & - \\
\hline C10A2NS3 & 0.4 & 85 & - & - & - & 10 & 2 & 3 & & - \\
\hline G40C7NS5NC3 & 0.4 & 45 & 40 & - & - & 7 & - & 5 & 3 & - \\
\hline G40C7NS5MC3 & 0.4 & 45 & 40 & - & - & 7 & - & 5 & - & 3 \\
\hline
\end{tabular}

\subsection{Test Methods}

To analyze the self-healing products generated in concrete cracks, the self-healing products must be separated from the cracks. Since concrete cracks are typically induced in irregular shapes, it is difficult to separate the existing cement matrix and the autogenous healing product. In this study, self-healing products were collected from artificial cracks using a method suggested by Huang et al. [36]. The detailed experimental method can be found in previous paper [38].

To generate artificial cracks, 32 paste slice specimens with dimensions of $100 \mathrm{~mm} \times 100$ $\mathrm{mm} \times 10 \mathrm{~mm}$ were fabricated. These specimens were cured in a chamber at $20 \pm 1{ }^{\circ} \mathrm{C}$ and $100 \% \mathrm{RH}$ for $24 \mathrm{~h}$. After $24 \mathrm{~h}$, the specimens were demolded and cured in a water container at $20 \pm 1{ }^{\circ} \mathrm{C}$ until the age of seven days. At the age of seven days, they were dried in an oven at $40 \pm 1{ }^{\circ} \mathrm{C}$ for $4 \mathrm{~h}$. The surfaces of the dried specimens were polished to expose the unreacted materials inside them with a polishing depth of $0.1 \mathrm{~mm}$ or more. A $100 \mu \mathrm{m}$-thick polyester film was laid on the interfaces of each polished specimen and fixed using a tape. The bundle specimens in which artificial cracks were generated were placed on a 20 -mm-thick spacer, and tap water was poured, such that $5 \mathrm{~mm}$ of the bottom of the specimen would contact the water. Figure 3 shows experimental diagram of the artificial crack method

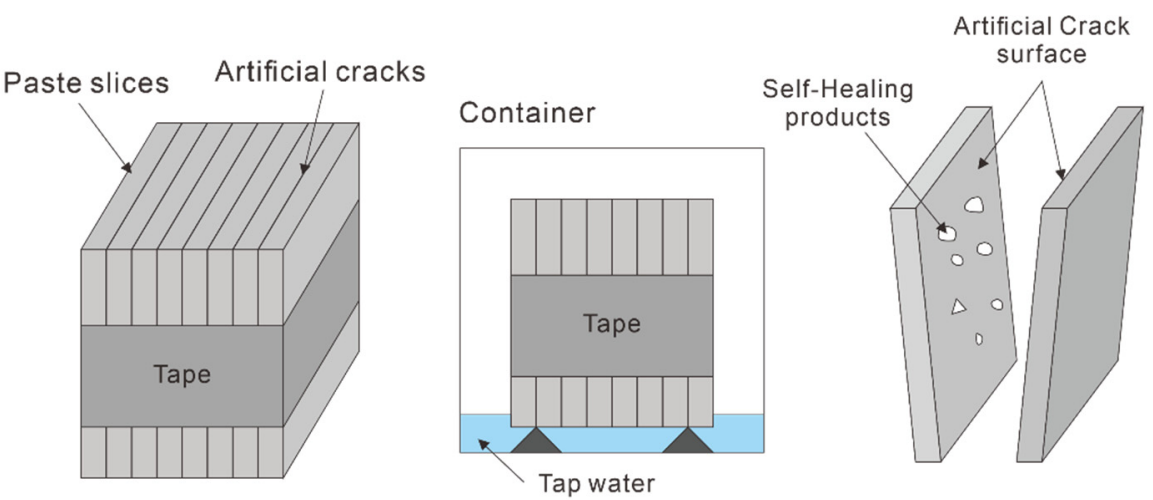

Figure 3. Experimental diagram of the artificial crack method [36]. 
All the bundle specimens were separated after immersion for seven days. Immediately after separating them, the self-healing products were collected from the artificial cracks using a plastic putter. The self-healing products were dried in an oven at $40 \pm 1{ }^{\circ} \mathrm{C}$ for $24 \mathrm{~h}$, and the hydration of self-healing products was stopped using isopropanol before conducting a chemical and phase composition analysis (XRD, TG/DTG, and SEM-EDS). After the self-healing products were immersed in isopropanol for $24 \mathrm{~h}$ with a solid/liquid ratio of $1 / 50$, hydration was stopped by replacing the solvent through vacuum. Subsequently, the self-healing products were kept in the isopropanol in a chamber at $23 \pm 1{ }^{\circ} \mathrm{C}$ until the chemical composition analysis was performed. To examine the chemical composition and morphology, powder samples smaller than $75 \mu \mathrm{m}$ were prepared by grinding the products.

In this study, the phase composition of self-healing products was investigated using XRD/Rietveld refinement and TG/DTG analysis. A PANalytical X'Pert Pro MRD diffractometer (Malvern Panalytical, Malvern, UK) equipped with a X'Celerator detector was used for the XRD measurement. The diffractometer scan was performed at $2 \theta$ values ranging from 10 to $60^{\circ}$ with a step size of $0.04^{\circ}$ and a counting time of $2 \mathrm{~s}$. A Rietveld quantitative phase analysis was performed to quantify the crystalline mass using the X'Pert HighScore Plus (PANalytical) software (Malvern Panalytical, Malvern, UK). For the internal standard material, $10 \%$ corundum was added. The contents of portlandite and calcite in the self-healing products were analyzed using thermogravimetry/derivative thermogravimetry (TG/DTG). For the TG/DTG analysis, a Thermo Plus EVO II (Rigaku, Tokyo, Japan) was used. The TG/DTG analysis was performed while heating the specimens at a rate of $10{ }^{\circ} \mathrm{C} / \mathrm{min}$ in a nitrogen atmosphere of $300 \mathrm{~mL} / \mathrm{min}$, and the measurement temperature range was $20-1000^{\circ} \mathrm{C}$.

The morphology and chemical composition of self-healing products were investigated using a field emission scanning electron microscope (FE-SEM, HITACHI SU 8220, Tokyo, Japan) at $15 \mathrm{kV}$ and a working distance (WD) of $15.8 \mathrm{~mm}$.

\section{Results and Discussion}

\subsection{Quantitative Analysis of Hydration Products in Cracks}

Figure 4a shows the backscatter electron (BSE) images of the self-healing products generated in an artificial crack of G40NS5. The product was generated on the crack surface through further hydration of the unreacted material on the crack surface between approximately $100-\mu \mathrm{m}$ artificial cracks. The black and white image in Figure $4 \mathrm{~b}$ shows the existing paste, and the colored areas represent the additional self-healing products generated during the seven-day autogenous healing period. The self-healing products were collected carefully using a plastic putter to prevent wearing of the existing cement matrix. The quantity of the collected sample was measured and its composition was analyzed.

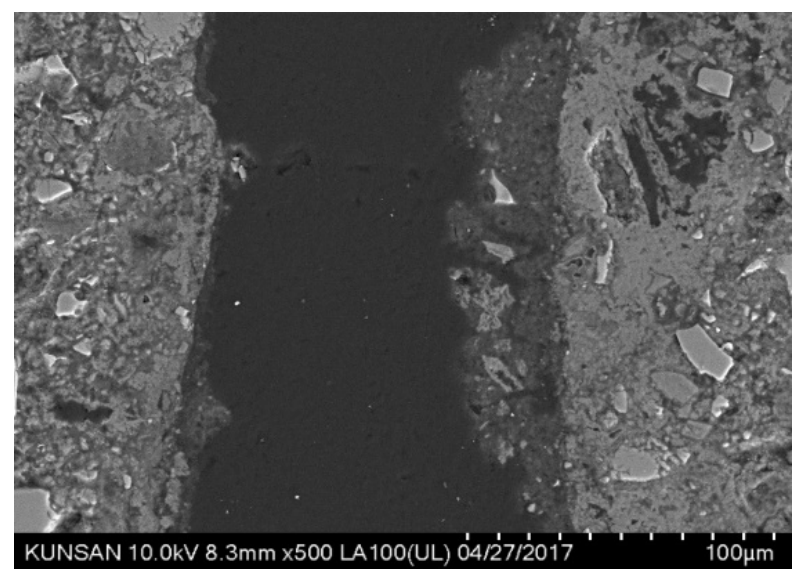

(a)

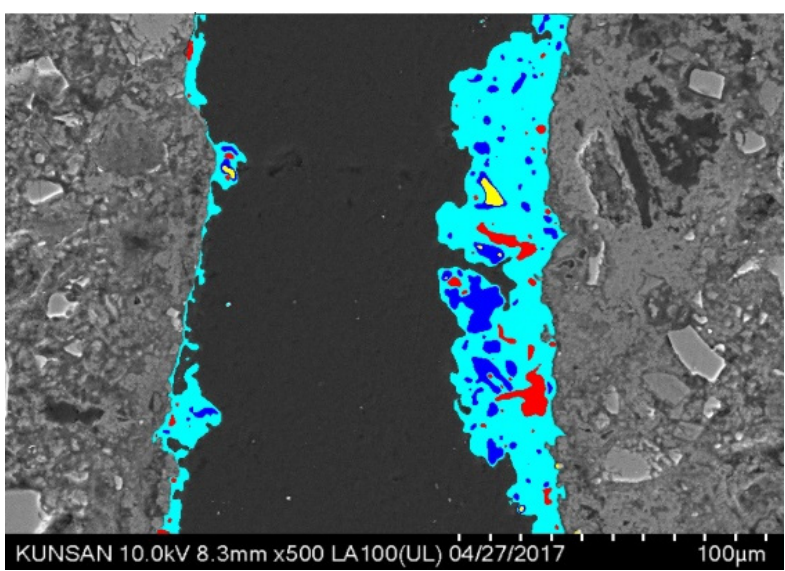

(b)

Figure 4. Artificial crack and self-healing product (G40NS5). (a) BSE image. (b) Self-healing product. 
Figure 5 shows the quantities of the self-healing products generated in the artificial cracks. The Y-axis indicates the contents of self-healing products generated in the cracks shown in units of amount per crack surface area $\left(\mathrm{g} / \mathrm{m}^{2}\right)$. The quantities of the products were indicated by the content of the product per crack surface. The quantities of the products were measured after the content of the self-healing product of P100 was $11.49 \mathrm{~g} / \mathrm{m}^{2}$. The graph shows that in the case of specimens containing GGBFS and FA, the contents of self-healing products decreased regardless of the replacement ratio. For FA, the content decreased to less than half of the P100. This was because as the replacement ratio of FA increased, the OPC content decreased, and the amount of $\mathrm{Ca}(\mathrm{OH})_{2}$ generated by the hydration of OPC decreased. Subsequently, the pozzolanic reaction decreased due to the reduction of $\mathrm{Ca}(\mathrm{OH})_{2}$ [39]. The GGBFS also showed a reduction in the self-healing products with an increasing replacement ratio. This is inconsistent with an existing finding, which showed that autogenous healing performance improves at higher replacement ratios of GGBFS $[21,40]$. Since the cracking of the specimen was induced at the age of seven days, the OPC also had a large amount of unreacted binder, and the reaction of GGBFS did not occur sufficiently because of the short self-healing period of seven days, which is shorter than that observed in other studies [21,40]. The reaction of FA started after the generation of $\mathrm{Ca}(\mathrm{OH})_{2}$ from the reaction of OPC [41]. Thus, it seems that the reaction of GGBFS did not occur because there was an insufficient amount of $\mathrm{Ca}(\mathrm{OH})_{2}$ inside the cracks. In the case of the specimen that contained both SF and CSA, the self-healing product content was similar to that of P100. By contrast, in the cases of G40NS5, C10A2NS3, and G40C7NS5NC3, which contained CAs, the self-healing product content increased compared to P100. G40NS5 exhibited a self-healing product content approximately twice that of G40. This was because $\mathrm{Na}_{2} \mathrm{SO}_{4}$ promoted the reaction of OPC and GGBFS [42]. In the cases of C10A2NS3 and G40C7NS5NC3, the self-healing products appear to have increased because anhydrite and $\mathrm{Na}_{2} \mathrm{SO}_{4}$ promoted the reaction.

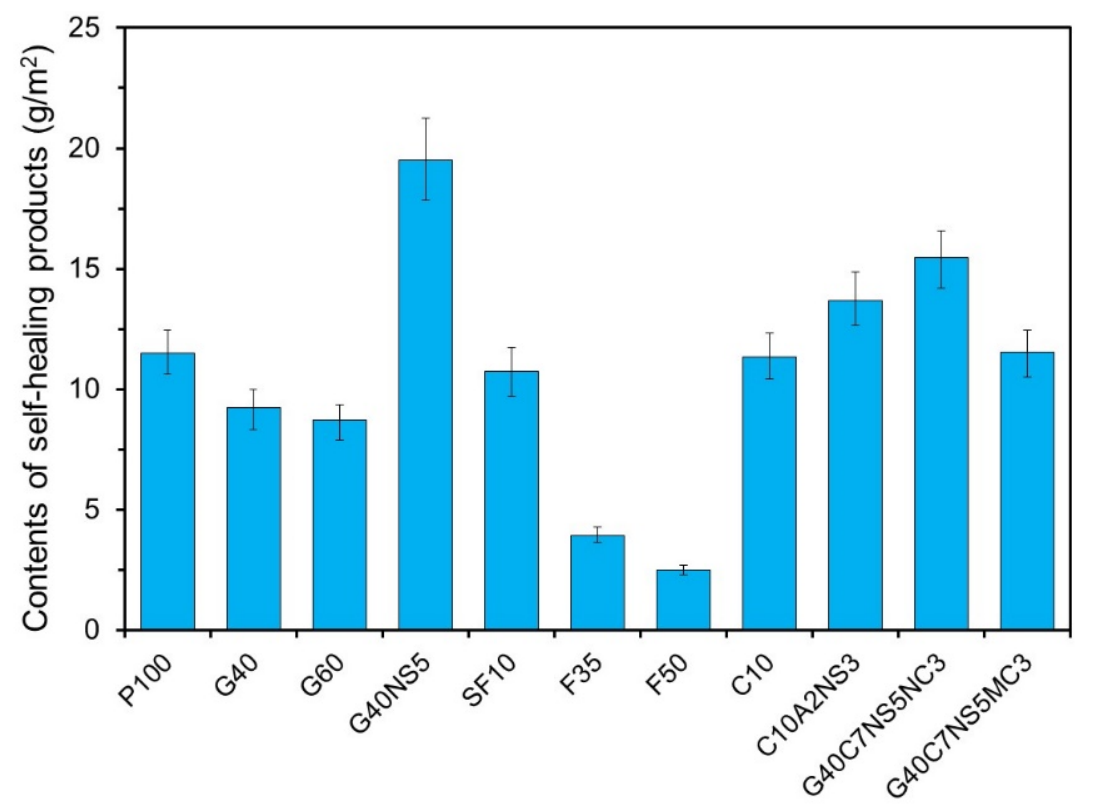

Figure 5. Contents of self-healing products in artificial cracks.

\subsection{XRD Analysis}

Figure 6 shows the XRD patterns of the self-healing products. In the case of P100, peaks of calcite and portlandite mainly appeared. It seems that portlandite was generated with the further hydration of OPC, and calcite with the further hydration of OPC and the reaction between $\mathrm{Ca}^{2+}$ and $\mathrm{CO}_{3}{ }^{2-}$ from the dissolution of $\mathrm{CO}_{2}$. In the case of $\mathrm{G} 40$ and $\mathrm{G} 60$, the peak of portlandite decreased, and peaks of calcite and bayerite were observed. The peak of portlandite decreased because portlandite was consumed in the reaction of the 
unreacted GGBFS. For SF10, quartz appeared in addition to calcite and portlandite. The quartz seems to have originated from SF. As with G40 and G60, the peak of portlandite decreased in FA35 and FA50, and the peak of bayerite appeared. In the case of C10 and C10A2NS3, the peak of calcite was observed, with some peaks of quartz, portlandite, bayerite, and aphthitalite. Aphthitalite was likely generated due to the anhydrite in the CSA. Similar to G40, G40NS5 exhibited a small portlandite peak, whereas aphthitalite and thermonatrite were generated by $\mathrm{Na}_{2} \mathrm{SO}_{4}$.

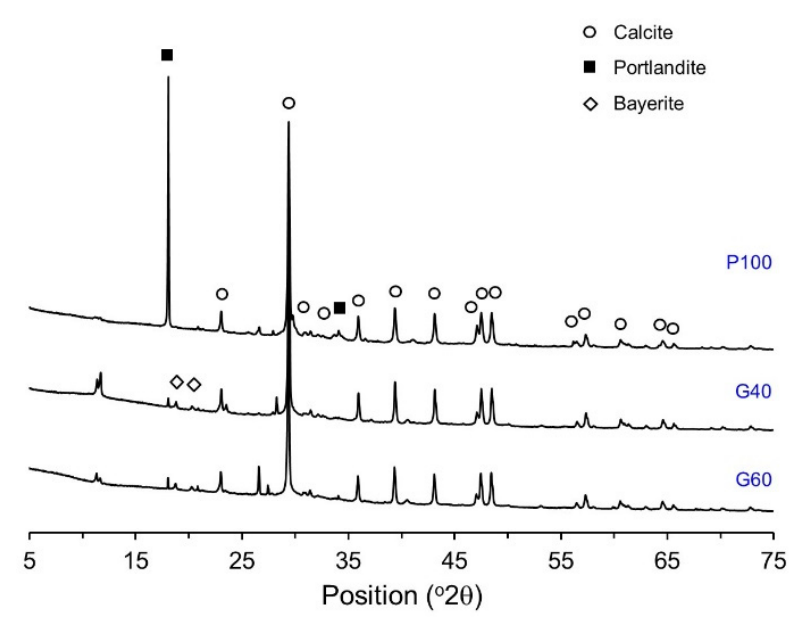

(a)

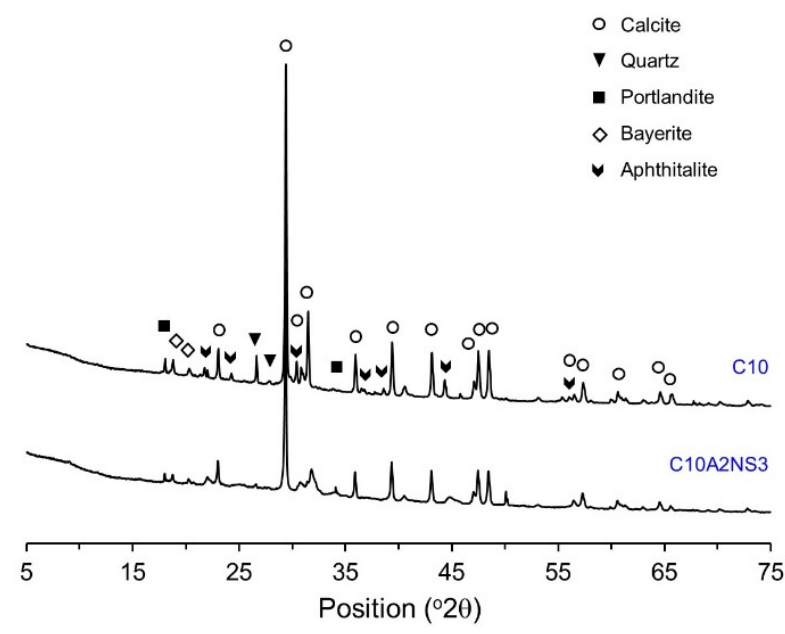

(c)

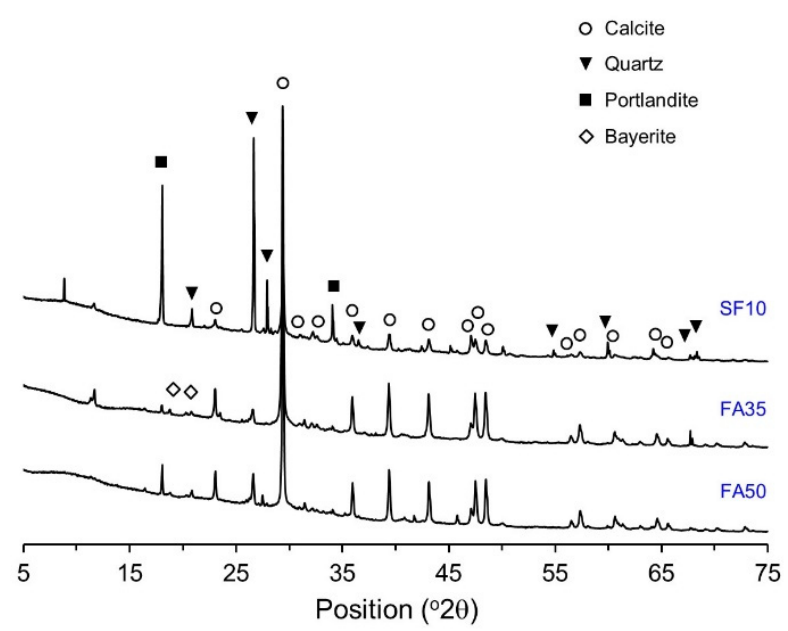

(b)

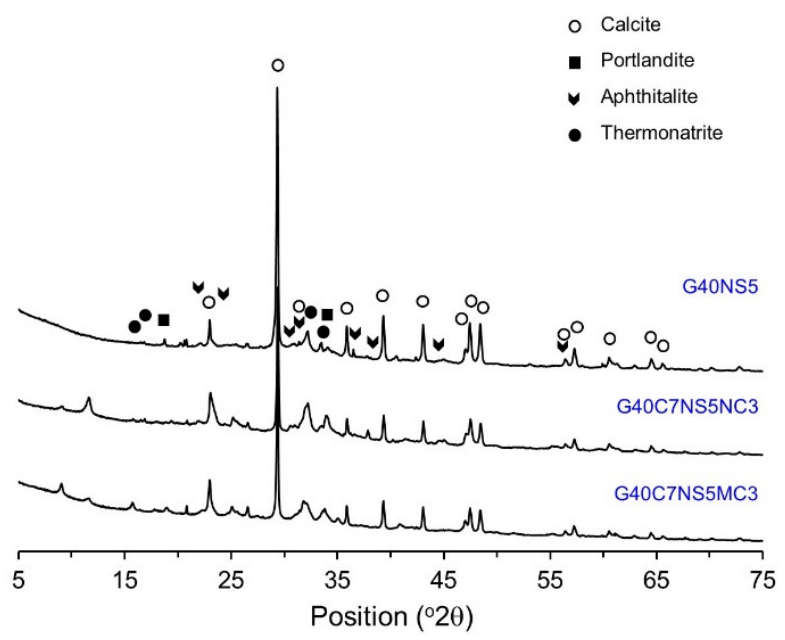

(d)

Figure 6. XRD patterns of self-healing products. (a) P100, G40, G60. (b) SF10, FA35, FA50. (c) C10, C10A2NS3. (d) G40NS5, G40C7NS5NC3, G40C7NS5MC3.

Table 3 lists the quantitative analysis results of the crystal phase of the self-healing products obtained by Rietveld refinement based on the XRD pattern experimental results of each specimen. In this table, amorphous means a hydrate that is not crystalline. The main components of the self-healing products generated from P100 were calcite and portlandite, with proportions of $33 \%$ and $23 \%$, respectively. In the case of G40 and G60, bayerite appeared in addition to calcite and portlandite. With an increase in the mixture proportion of GGBFS, the portlandite content decreased, because portlandite was consumed in the hydration of GGBFS. The proportions of calcite in the G40 and G60 were 37\% and 32\%, respectively, similar to P100. As with P100, the main components of SF10, F35, and F50 were calcite and portlandite. In the case of SF10, the proportions of calcite and portlandite were $29 \%$ and $17 \%$, respectively, a slight decrease compared to P100, but not a large difference. As for F35, the proportion of calcite was 32\%, similar to that of P100; however, 
the proportion of portlandite decreased to $11 \%$ because the portlandite was consumed in the Pozzolan reaction of FA. In the case of F50, both the calcite and portlandite contents decreased compared to P100. This was likely because the proportion of portlandite and the $\mathrm{pH}$ were insufficient for the reaction of FA.

Table 3. Phase composition of self-healing products by Rietveld refinement.

\begin{tabular}{|c|c|c|c|c|c|c|}
\hline & \multicolumn{6}{|c|}{ Self-Healing Products (wt. \%) } \\
\hline & Amorphous & $\begin{array}{c}\text { Calcium } \\
\text { Carbonate } \\
\left(\mathrm{CaCO}_{3}\right)\end{array}$ & $\begin{array}{l}\text { Portlandite } \\
\left(\mathrm{Ca}(\mathrm{OH})_{2}\right)\end{array}$ & $\begin{array}{l}\text { Alkali Sulfate } \\
(\mathrm{K}, \mathrm{Na})_{3} \mathrm{Na}\left(\mathrm{SO}_{4}\right)_{2}\end{array}$ & $\begin{array}{c}\text { Bayerite } \\
\left(\mathrm{Al}(\mathrm{OH})_{3}\right)\end{array}$ & $\begin{array}{c}\text { Alkali } \\
\text { Carbonate } \\
\left(\mathrm{Na}_{2} \mathrm{CO}_{3} \cdot \mathrm{H}_{2} \mathrm{O}\right)\end{array}$ \\
\hline P100 & 44 & 33 & 23 & - & - & - \\
\hline G40 & 47 & 37 & 14 & - & 2 & - \\
\hline G60 & 63 & 32 & 4 & - & 1 & - \\
\hline G40NS5 & 60 & 31 & 7 & 1 & $<1$ & 1 \\
\hline SF10 & 54 & 29 & 17 & - & & - \\
\hline F35 & 57 & 32 & 11 & - & & - \\
\hline F50 & 79 & 12 & 9 & - & - & - \\
\hline C10 & 47 & 39 & 2 & 9 & 3 & - \\
\hline C10A2NS3 & 66 & 24 & - & 8 & 2 & - \\
\hline G40C7NS5NC3 & 63 & 16 & - & 18 & - & 3 \\
\hline G40C7NS5MC3 & 73 & 20 & - & 7 & - & $<1$ \\
\hline
\end{tabular}

In the case of G40NS5 to which $\mathrm{Na}_{2} \mathrm{SO}_{4}$ was added, the proportion of portlandite decreased compared to G40, while aphthitalite, a type of alkali sulfate, and thermonatrite, a type of alkali carbonate, were generated. It seems that aphthitalite and thermonatrite were generated because $\mathrm{Na}^{2+}$, which was dissolved from $\mathrm{Na}_{2} \mathrm{SO}_{4}$, flowed through the cracks and reacted with $\mathrm{SO}_{4}{ }^{2-}$ and $\mathrm{CO}_{3}{ }^{2-}$. In the $\mathrm{C} 10$ and C10A2NS3, which contained a CSA expansion agent, the proportion of portlandite decreased the most, while aphthitalite and bayerite were generated. C10 exhibited the highest proportion of calcite at $39 \%$, while containing $9 \%$ aphthitalite and 3\% bayerite. In the case of C10A2NS3, the proportion of calcite was $24 \%$, which was lower than that of P100, whereas the proportions of aphthitalite and bayerite were $8 \%$ and $2 \%$, respectively. As for G40C7NS5NC3 and G40C7NS5MC3, the main components were calcite, aphthitalite, which is an alkali sulfate, and thermonatrite, which is an alkali carbonate. For G40C7NS5NC3, the proportion of aphthitalite was $18 \%$, which was higher than the proportion of calcite. The quantitative analysis results of the self-healing products showed that calcite accounted for the highest proportion in every specimen, excluding G40C7NS5NC3. Therefore, calcite was concluded to be the main component in the self-healing products. An autogenous healing product varies with the type of mineral admixture used. When CAs were used, the results showed other types of compounds that did not appear in P100.

\subsection{TG/DTG Analysis}

In this study, the components of self-healing healing were analyzed using TG/DTG analysis. The decomposed materials of hydrates differ by temperature. The weight of C-S- $\mathrm{H}$ decreases because $\mathrm{H}_{2} \mathrm{O}$ evaporates at $200{ }^{\circ} \mathrm{C}$ or lower [43]. Bayerite $\left(\mathrm{Al}(\mathrm{OH})_{3}\right)$ is decomposed in the temperature range of $180-250{ }^{\circ} \mathrm{C}$ [44]. For portlandite $(\mathrm{CH})$, the decomposition of $\mathrm{H}_{2} \mathrm{O}$ occurs in the temperature range of $400-550^{\circ} \mathrm{C}$, and for calcite, the decomposition of $\mathrm{CO}_{2}$ occurs in the temperature range of $550-850{ }^{\circ} \mathrm{C}$ [45].

Figure 7 shows the TG/DTG analysis results. In the case of P100, the weight changed because of the decompositions of C-S-H, CH, and calcite. The weight changes due to the decompositions of $\mathrm{CH}$ and calcite were particularly significant, indicating that the selfhealing products contained large amounts of $\mathrm{CH}$ and calcite. In contrast to P100, G40 and G60 exhibited weight changes due to the decomposition of bayerite, and the weight change due to the decomposition of $\mathrm{CH}$ was lower than of P100. It appears as if GGBFS reacted 
with $\mathrm{CH}$ to form bayerite. $\mathrm{G} 60$ did not show any weight change due to the decomposition of $\mathrm{CH}$. It appears that $\mathrm{G} 60$ does not form the $\mathrm{CH}$ required for GGBFS to react due to its low OPC. G40 and G60 showed significant weight changes due to the decomposition of calcite, albeit to a lower extent than in P100. In G40 and G60, the concentration of $\mathrm{Ca}^{2+}$ in the pores was smaller than that of OPC, so it seems that the generation of calcite decreased. There was no difference in the weight of calcite due to the replacement ratio of GGBFS. In the cases of F35 and F50, the weight changed because of the decompositions of $\mathrm{CH}$ and calcite. The $\mathrm{CH}$ content decreased significantly compared to that of $\mathrm{P} 100$ regardless of the mixture proportion of FA, because $\mathrm{CH}$ was consumed by the pozzolanic reaction of FA. The calcite content in F35 was similar to that in P100, whereas the calcite content in F50 decreased. SF10 and P100 exhibited similar shapes on the graph. When 10\% silica fume was used, it did not yield any significant effect on the contents of C-S- $\mathrm{H}$, calcite, and $\mathrm{Ca}(\mathrm{OH})_{2}$, which were present in the self-healing products.

In the cases of C10 and C10A2NS3, the weight changed because of the decompositions of C-S-H, bayerite, alkali sulfate, and calcite. The weight change due to the decomposition of C-S-H was similar to that in the case of P100. Results of XRD/Rietveld refinement analysis also show alkali sulfate in C10 and C10A2NS3. Figure 7d shows the thermal gravimetric analysis results of G40NS5, G40C7NS5NC3, and G40C7NS5MC3. The graphs show that the weight changes of G40C7NS5NC3 and G40C7NS5MC3 due to the decomposition of C-S-H were greater than that of G40NS5. This section is where the weight change due to the decomposition of C-S-H generally appears, and G40C7NS5MC3 showed a significant weight change in this section. A weight change due to the decomposition of $\mathrm{Ca}(\mathrm{OH})_{2}$ appeared only in G40NS5, and it was similar to that of G40. The weight change due to the decomposition of calcite was lower than that of G40, and the weight change of G40C7NS5NC3 was the lowest. However, in the case of G40C7NS5NC3, a small weight change due to the decomposition of alkali carbonate was observed. The XRD analysis result also showed that G40C7NS5NC3 produced 3\% alkali carbonate.

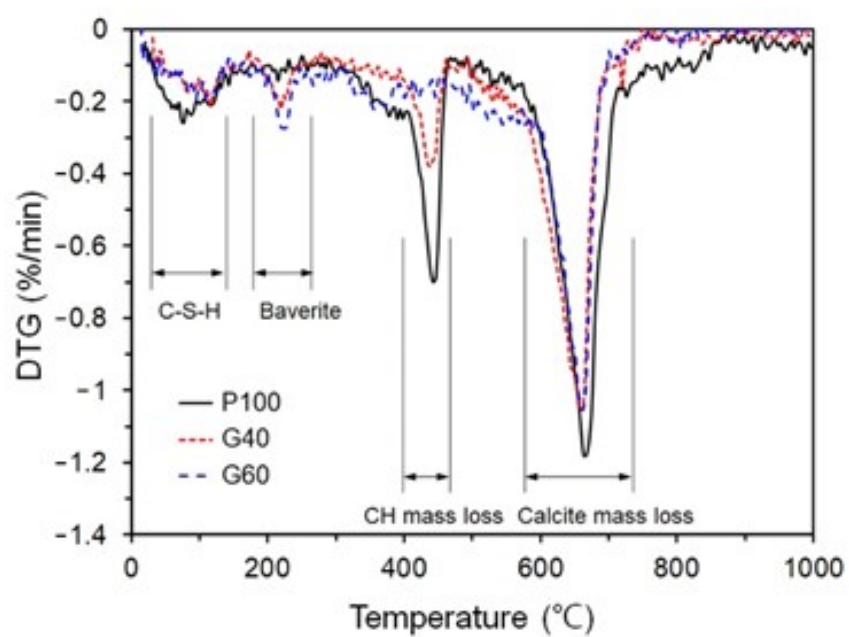

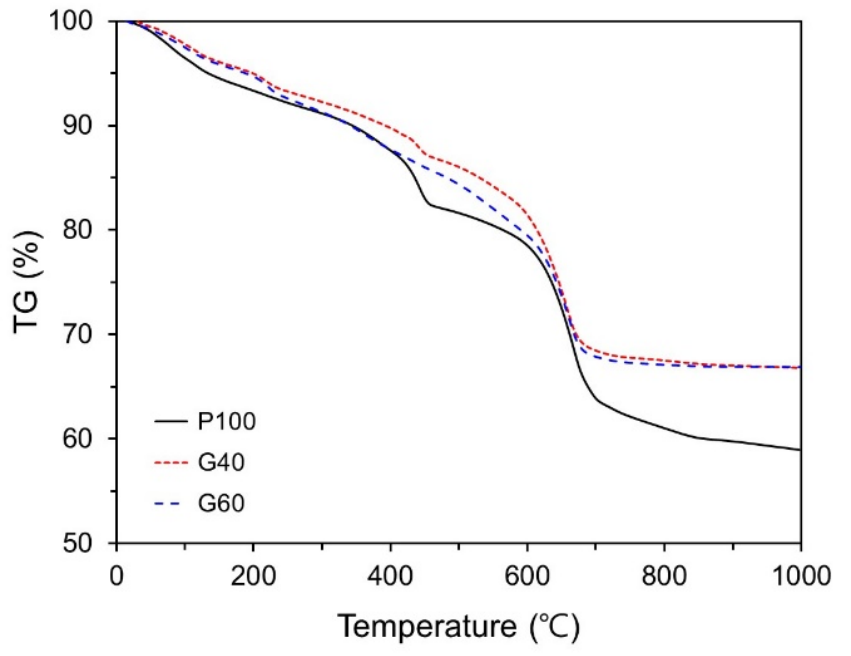

(a)

Figure 7. Cont. 

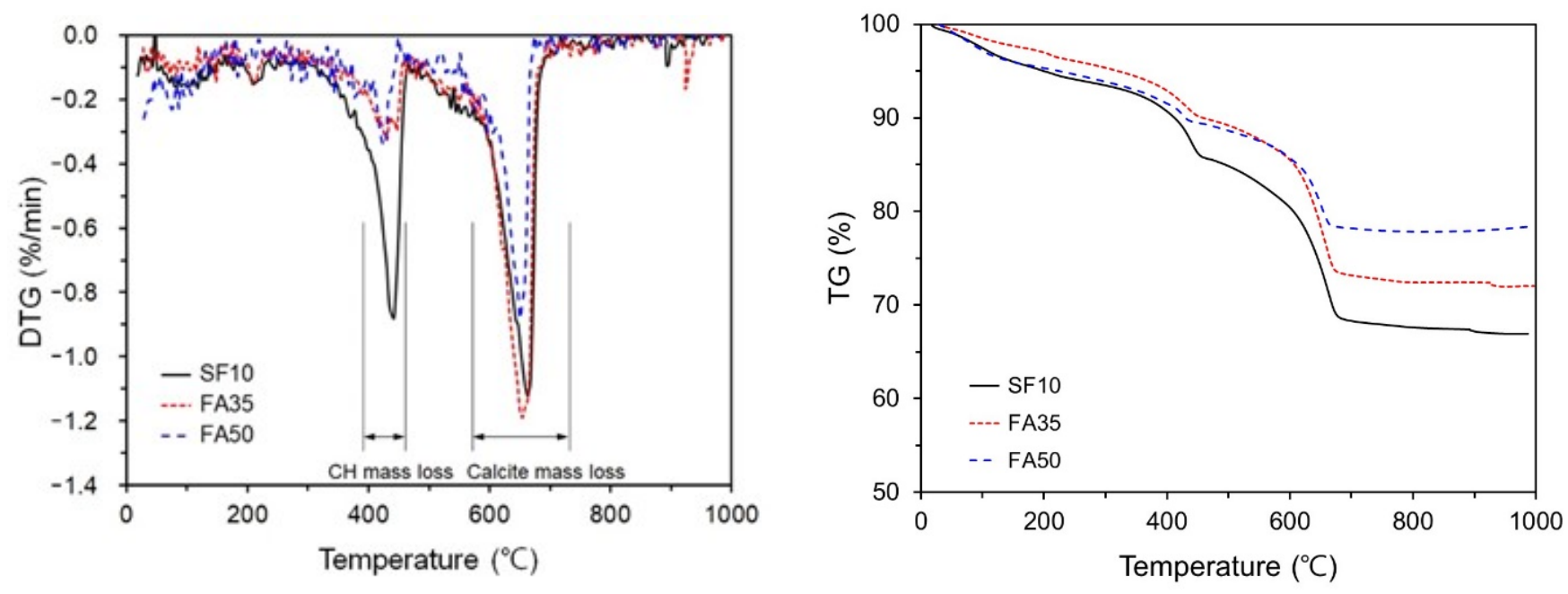

(b)
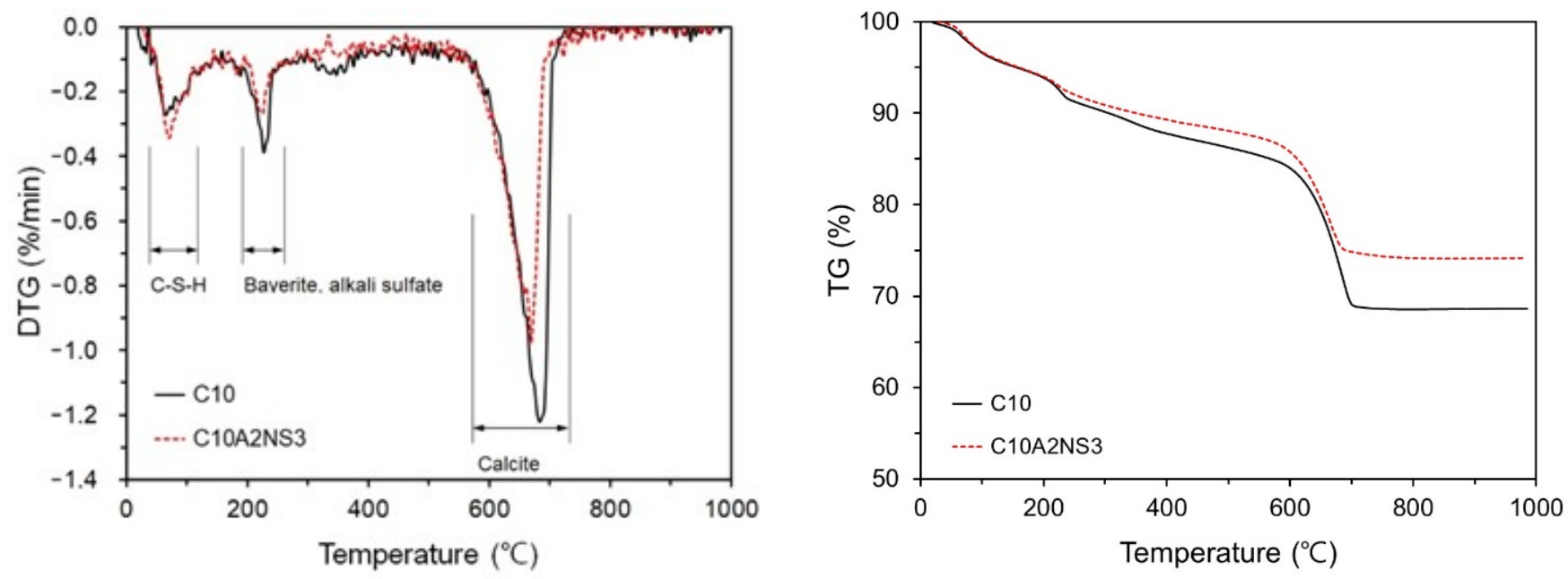

(c)
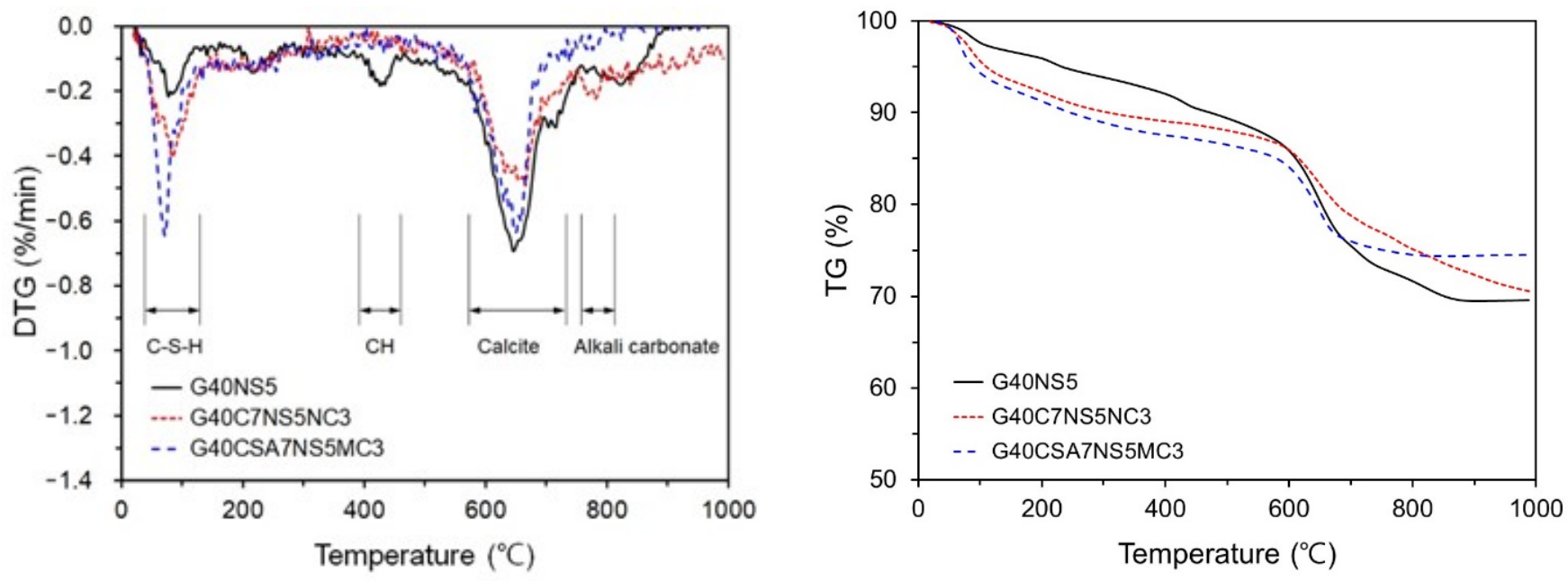

(d)

Figure 7. Thermal gravimetric analysis results of self-healing products. (a) P100, G40, G60. (b) SF10, FA35, FA50. (c) C10, C10A2NS3. (d) G40NS5, G40C7NS5NC3, G40C7NS5MC3. 
Figure 8 shows the contents of calcite and $\mathrm{CH}$ measured from the XRD/Rietveld refinement and TG analyses. Y-axis indicates the contents of calcite and $\mathrm{CH}$ generated in cracks shown in units of amount per crack surface area $\left(\mathrm{g} / \mathrm{m}^{2}\right)$. The graph shows that the quantitative analysis results of XRD/Rietveld refinement and TG/DTG analysis were similar. Except for F35 and F50, the calcite content was higher by $2.3 \mathrm{~g} / \mathrm{m}^{2}$ or more. In F35 and F50, the calcite contents were very low: $1.26 \mathrm{~g} / \mathrm{m}^{2}$ and $0.3 \mathrm{~g} / \mathrm{m}^{2}$, respectively. When a mineral admixture was added, the calcite content in the self-healing products was lower than in P100, except for G40NS5 and C10. In the case of G40NS5, the calcite content increased by more than $60 \%$, which was likely because $\mathrm{Na}_{2} \mathrm{SO}_{4}$ promoted the reaction between OPC and GGBFS [42]. The portlandite content was highest in P100, and it decreased when the mineral admixture was added. In particular, portlandite did not appear in G60, C10, C10A2NS3, G40C7NS5NC3, and G40C7NS5MC3. Portlandite is a product of cement hydration, and its content decreases if OPC is replaced by another binder. Furthermore, GGBFS and FA produce a silicate gel by consuming portlandite, which seems to be the reason for the decrease in the portlandite content. Compared with previous findings that showed improvement in autogenous healing performance owing to the addition of SCMs and CAs, portlandite was not found to be advantageous for autogenous healing performance in our study $[46,47]$.

Park and Choi [48] investigated self-healing potential in terms of the mixture proportions of OPC, GGBFS, FA, SF, CSA, and crystalline additives. After cracking, the hydration heat from the further hydration of unreacted binder was measured using isothermal calorimetry. It was predicted that the higher the hydration heat, the greater the amount of self-healing products generated. In the case of GGBFS, it was predicted that the higher the replacement ratio, the more the self-healing products due to further hydration. This result was different from that shown in Figure 8, where P100 is found to contain more self-healing products than G40 and G60. Figure 8 only shows the results of the calcite and portlandite, with no data pertaining to the quantitative analysis results of other phase compositions. Qiu et al. [49] reported the existence of C-S-H in the self-healing products of specimens containing GGBFS. Since a self-healing product is composed of various phase compositions, it is difficult to evaluate autogenous healing performance only by a quantitative analysis of the calcite and portlandite. Park and Choi [48] found that the higher the replacement ratio of FA, the lower the hydration heat, and the self-healing products were expected to decrease. This is similar to the result shown in Figure 8, and it is expected to improve the autogenous healing performance. However, the findings of some studies differed from ours. Tittelboom et al. [21] reported that the healing performance improved when the replacement ratio of FA was 35\% based on a crack closing test. In addition, Park and Choi [47] reported that replacing FA increased the autogenous healing performance compared to the plain case based on a water flow test. These findings suggest that the autogenous healing performance is affected by factors other than the phase compositions and volume of the self-healing products. Roig-Flores et al. [25] reported that the autogenous healing performance was affected by the crack geometry. Park and Choi [48] examined the self-healing potential for mixtures with $10 \%$ replacements of SF and CSA. In the case of C10 in Figure 8, the calcite content increased compared to P100; however, the portlandite content decreased, and the calcite and portlandite contents of SF10 also decreased. Therefore, it can be concluded that phases other than calcite and portlandite were generated. 


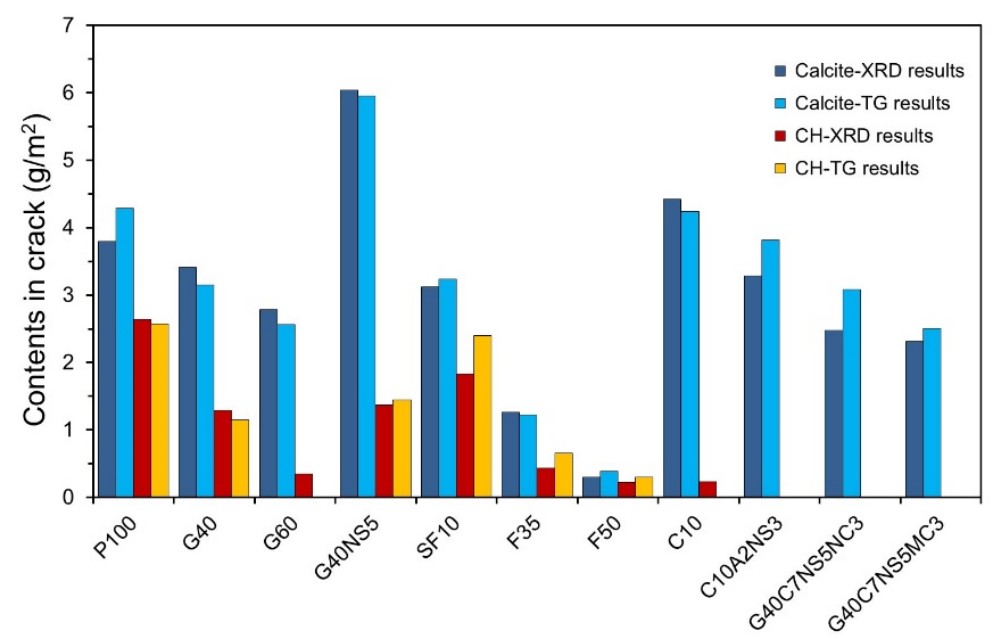

Figure 8. Calcite and portlandite contents of self-healing products.

\subsection{SEM-EDS Analysis}

In this study, the morphology and chemical composition of self-healing products were investigated using SEM-EDS analysis. Figure 9 shows the SEM images and EDS analysis results of the self-healing products. The self-healing products of P100 mainly comprise plate-type hydrates and hexahedral hydrates. The EDS analysis result showed particularly high peaks for $\mathrm{Ca}, \mathrm{C}$, and $\mathrm{O}$, and the hydrates were portlandite and calcite. G40 did not exhibit plate-type hydrates, and only some hexahedral hydrates appeared. The EDS analysis result showed high peaks for $\mathrm{Ca}, \mathrm{Si}, \mathrm{Al}$, and $\mathrm{O}$. Based on the EDS analysis result, it can be inferred that the major hydrate is C-S-H or C-A-H. The SEM image of G40N5 mainly showed hexahedral hydrates. The EDS analysis result indicated high peaks of $\mathrm{Ca}, \mathrm{C}$, and $\mathrm{O}$, suggesting the dominant presence of calcite. The XRD/Rietveld refinement and TG/DTG analysis results yielded the same finding. The SEM image of SF10 mainly showed hexahedral hydrates. The EDS analysis result showed peaks for $\mathrm{Ca}, \mathrm{Si}, \mathrm{C}$, and $\mathrm{O}$. This confirmed that calcite and C-S-H were mixed in the autogenous healing product. In the EDS analysis result of F35, the peaks of $\mathrm{Ca}, \mathrm{Al}$, and $\mathrm{Si}$ were high, much like the case of G40. Thus, the self-healing products were concluded to be C-S-H and C-A-H. C10 showed needle-like hydrates, and the peaks of $\mathrm{Ca}, \mathrm{Al}, \mathrm{S}$, and $\mathrm{O}$ mainly appeared in the EDS analysis result. Therefore, it is concluded that the autogenous healing product of C10 contains ettringite. C10A2NS3 mainly exhibited needle-like and hexahedral hydrates. The EDS analysis result also showed high peaks of $\mathrm{Ca}, \mathrm{Al}, \mathrm{S}, \mathrm{O}$, and $\mathrm{C}$, suggesting the presence of ettringite and calcite in the self-healing products. The SEM-EDS analysis of the self-healing products generated by C10 and C10A2NS3 showed that when CSA is used, the self-healing products could contain ettringite, which is an expandable hydrate. 


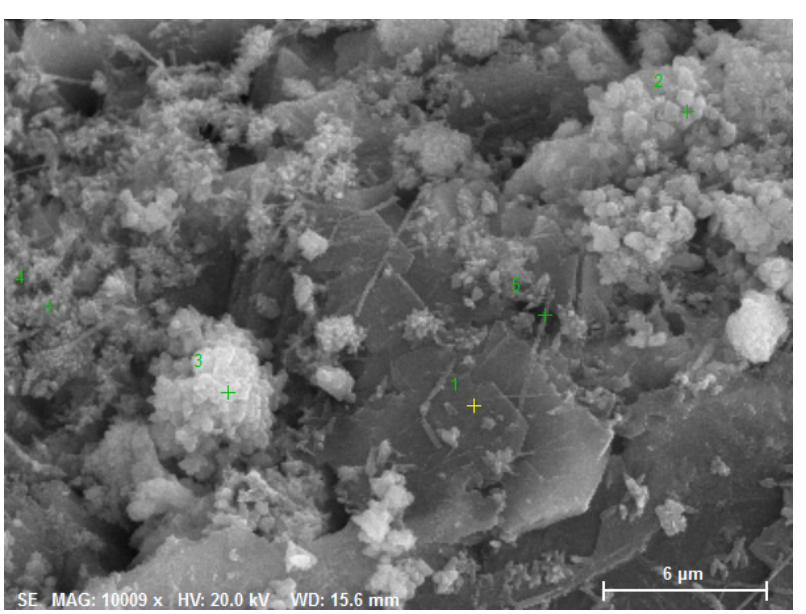

(a)

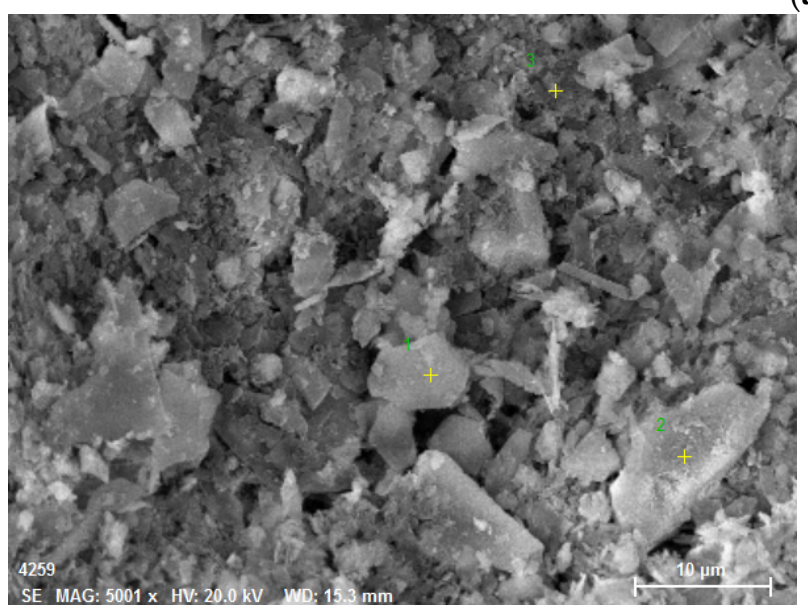

(b)

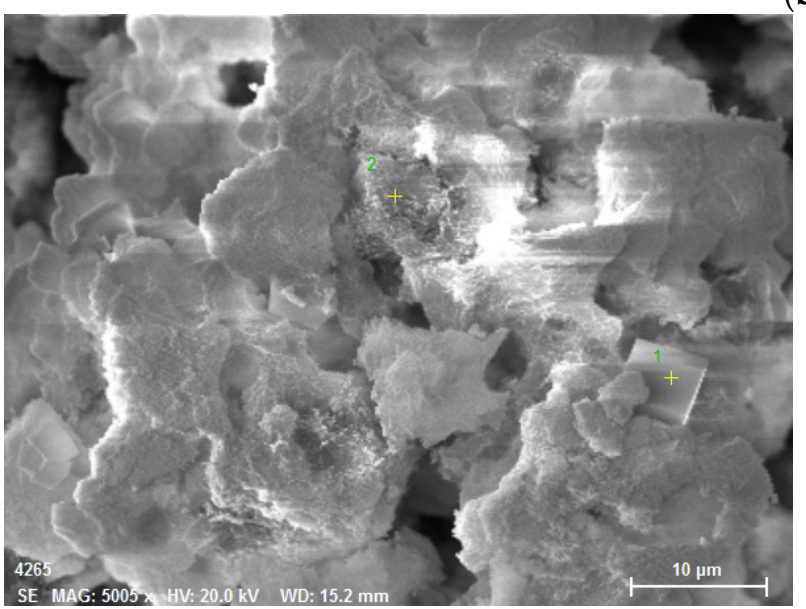

(c)
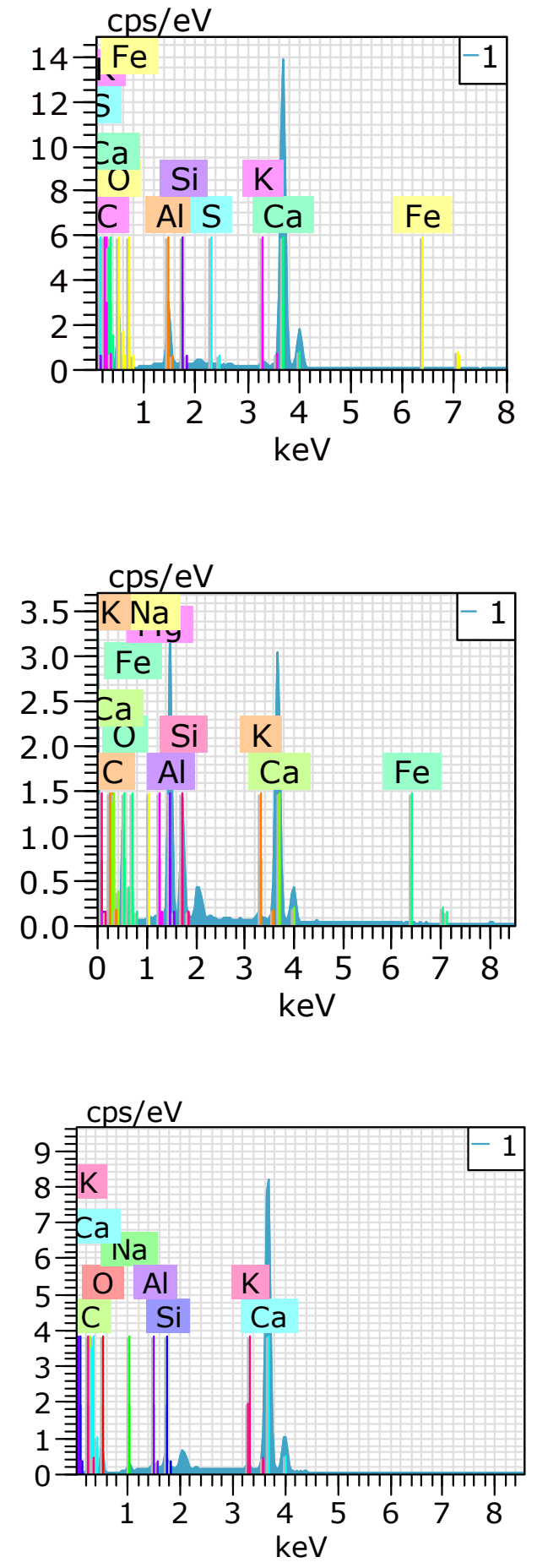

Figure 9. Cont. 


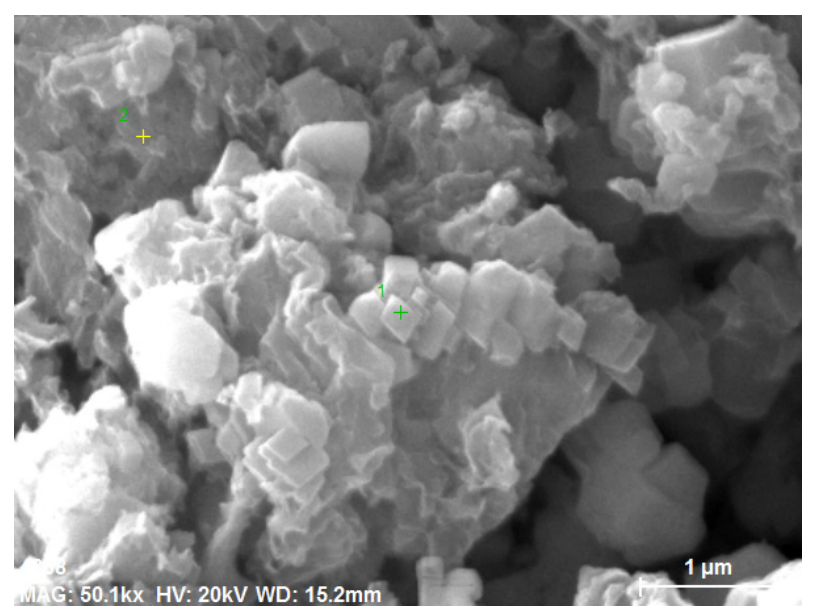

(d)
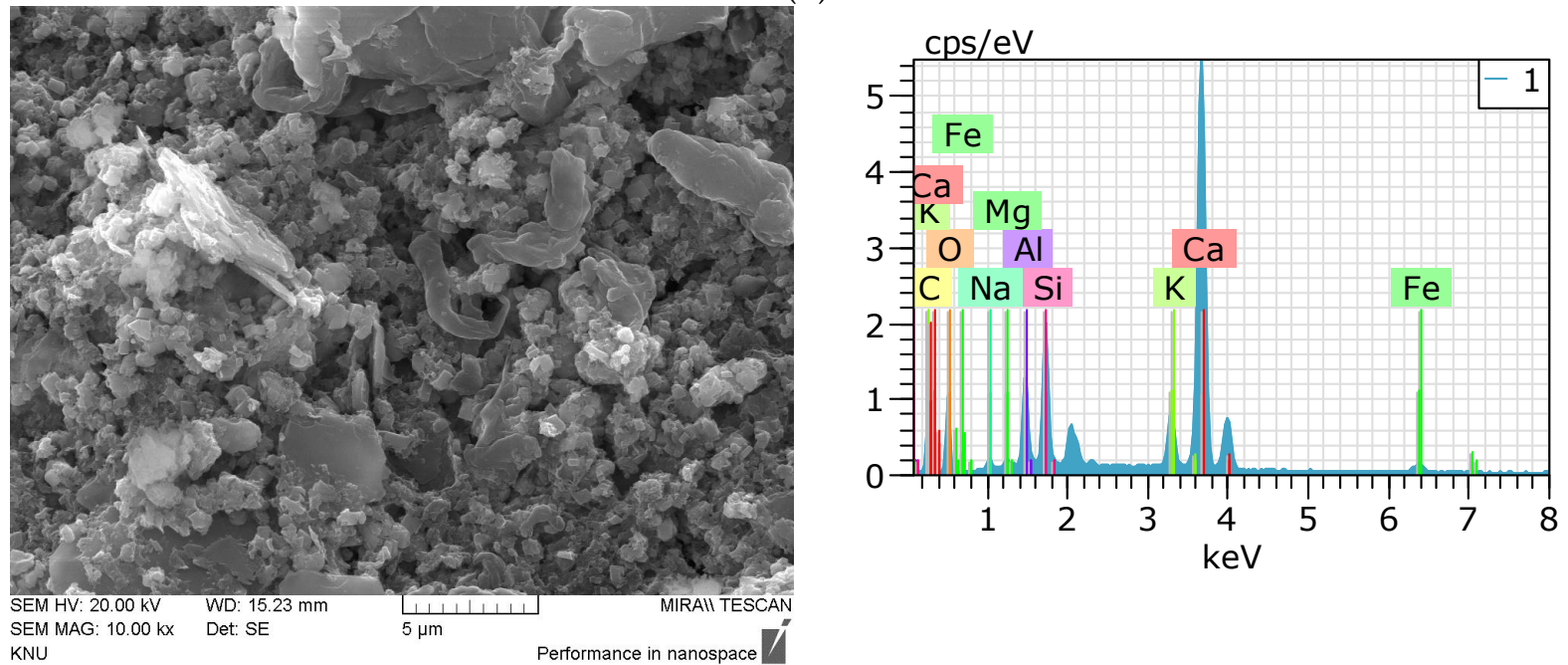

(e)
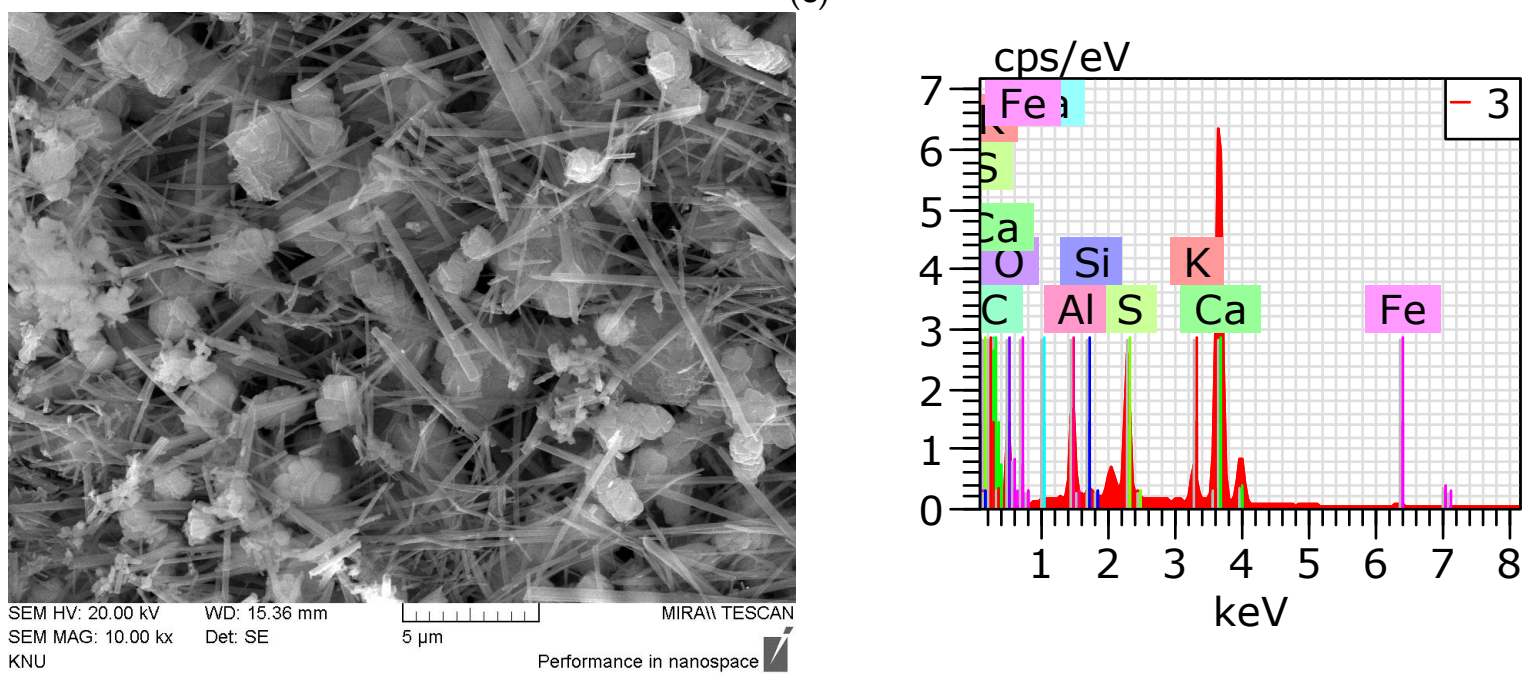

(f)

Figure 9. Cont. 


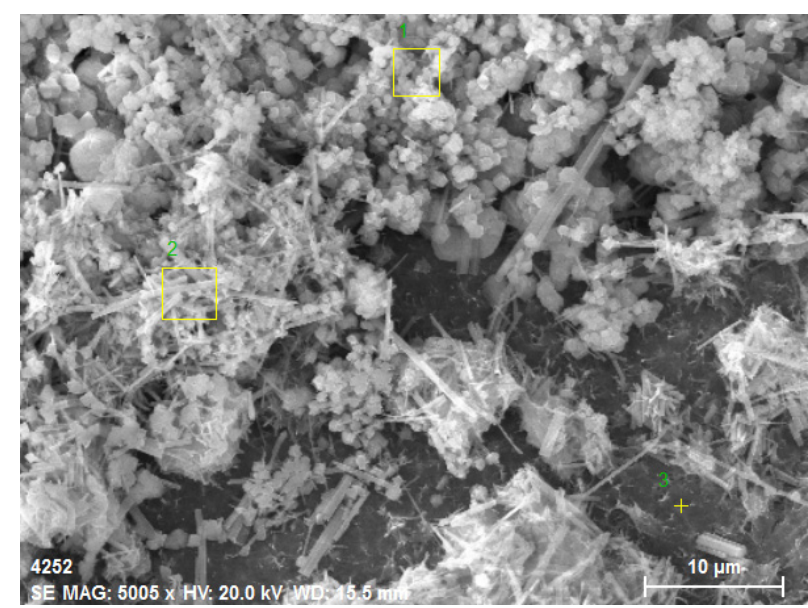

(g)

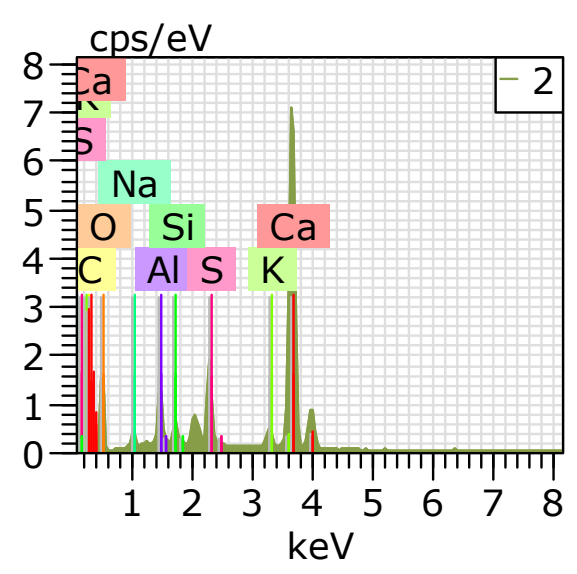

Figure 9. SEM-EDS observation results of self-healing products. (a) P100. (b) G40. (c) G40N5. (d) SF10. (e) F35. (f) C10. (g) C10A2NS3.

\section{Conclusions}

This study investigated the self-healing products of cement pastes mixed with SCMs and CAs. The self-healing products were quantified through XRD/Rietveld refinement and TG/DTG analysis, and the morphology and phase composition were analyzed using SEM-EDS. The findings of this study can be summarized as follows.

(1) The amount of self-healing products decreased when SCMs were used, whereas it increased when SCMs were used along with CAs. G40NS5 showed the highest content of self-healing products.

(2) The XRD/Rietveld refinement of the phase composition of the self-healing products showed that calcite was the main compound, irrespective of the mixture proportions. The portlandite content decreased when SCMs and crystalline additives were mixed. When CAs were mixed, alkali sulfate and alkali carbonate appeared. This indicates that the phase composition of self-healing products varies with the mixture proportions.

(3) The TG/DTG analysis results showed that the addition of GGBFS and FA significantly decreased the portlandite content in the self-healing products. In every specimen, the weight change due to the decomposition of calcite was the highest, and the calcite content decreased in the G40NS5, G40C7NS5NC3, and G40C7NS5MC3 with crystalline additives.

(4) The quantitative analysis results of calcite and portlandite obtained using the XRD/ Rietveld refinement and TG/DTG analysis methods were compared with the results of existing studies. The calcite and portlandite contents were not found to be proportional to the autogenous healing performance. This is believed to be due to the effect of different types of phase compositions in the self-healing products and the crack geometry.

(5) The SEM-EDS analysis results showed that portlandite and calcite were mainly observed in P100 and SF10. When SF was replaced with 10\%, the self-healing products were similar to the case using OPC alone. When GGBFS and FA were added, portlandite did not appear, and C-A-H and C-S-H mainly appeared. When the CSA was used, plate-type monosulfate and acicular ettringite appeared in the self-healing products, whereas plate-type and hexahedral hydrates mainly appeared in the G40NS5.

Author Contributions: Conceptualization, Y.-C.C.; methodology, B.P.; validation, Y.-C.C.; formal analysis, Y.-C.C. and B.P.; investigation, B.P.; data curation, B.P.; writing-original draft preparation, B.P.; writing-review and editing, B.P.; visualization, Y.-C.C.; supervision, Y.-C.C.; project administra- 
tion, Y.-C.C.; funding acquisition, Y.-C.C. All authors have read and agreed to the published version of the manuscript.

Funding: This work was supported by the Korea Institute of Energy Technology Evaluation and Planning (KETEP) and the Ministry of Trade, Industry and Energy (MOTIE) of the Republic of Korea (No. 20181110200070). This work was also supported by the Gachon University research fund of 2021 (GCU-202103420001).

Institutional Review Board Statement: Not applicable.

Informed Consent Statement: Not applicable.

Data Availability Statement: Not applicable.

Conflicts of Interest: The authors declare no conflict of interest.

\section{References}

1. Vantadori, S.; Carpinteri, A.; Guo, L.P.; Ronchei, C.; Zanichelli, A. Synergy assessment of hybrid reinforcements in concrete. Compos. Part B Eng. 2018, 147, 197-206. [CrossRef]

2. Wang, L.; Zhou, S.H.; Shi, Y.; Tang, S.W.; Chen, E. Effect of silica fume and PVA fiber on the abrasion resistance and volume stability of concrete. Compos. Part B Eng. 2017, 130, 28-37. [CrossRef]

3. Uno, P.J. Plastic shrinkage cracking and evaporation formulas. ACI Mater. J. 1998, 95, 365-375.

4. Wang, L.; Yang, H.Q.; Zhou, S.H.; Chen, E.; Tang, S.W. Mechanical properties, long-term hydration heat, shrinkage behavior and crack resistance of dam concrete designed with low heat Portland (LHP) cement and fly ash. Constr. Build. Mater. 2018, 187, 1073-1091. [CrossRef]

5. Li, K.; Li, L. Crack-altered durability properties and performance of structural concretes. Cem. Concr. Res. 2019, $124,105811$. [CrossRef]

6. Djerbi, A.; Bonnet, S.; Khelidj, A.; Baroghel-Bouny, V. Influence of traversing crack on chloride diffusion into concrete. Cem. Concr. Res. 2008, 38, 877-883. [CrossRef]

7. Zhang, W.; Zheng, Q.; Ashour, A.; Han, B. Self-healing cement concrete composites for resilient infrastructures: A Review. Compos. Part B Eng. 2020, 189, 107892. [CrossRef]

8. Vijay, K.; Murmu, M.; Deo, S.V. Bacteria based self-healing concrete-A review. Constr. Build. Mater. 2017, 152, 1008-1014. [CrossRef]

9. $\mathrm{Wu}, \mathrm{M}$.; Johannesson, B.; Geiker, M. A review: Self-healing in cementitious materials and engineered cementitious composite as a self-healing material. Constr. Build. Mater. 2012, 28, 571-583. [CrossRef]

10. Van Belleghem, B.; Zaccardi, Y.V.; Van den Heede, P.; Van Tittelboom, K.; De Belie, N. Evaluation and comparison of traditional methods and electron probe micro analysis (EPMA) to determine the chloride ingress perpendicular to cracks in self-healing concrete. Constr. Build. Mater. 2019, 227, 116789. [CrossRef]

11. Van Belleghem, B.; Kessler, S.; Van den Heede, P.; Van Tittelboom, K.; De Belie, N. Chloride induced reinforcement corrosion behavior in self-healing concrete with encapsulated polyurethane. Cem. Concr. Res. 2018, 113, 130-139. [CrossRef]

12. Gilabert, F.A.; Van Tittelboom, K.; Tsangouri, E.; Van Hemelrijck, D.; De Belie, N.; Van Paepegem, W. Determination of strength and debonding energy of a glass-concrete interface for encapsulation-based self-healing concrete. Cem. Concr. Compos. 2017, 79, 76-93. [CrossRef]

13. Maes, M.; Snoeck, D.; De Belie, N. Chloride penetration in cracked mortar and the influence of autogenous crack healing. Constr. Build. Mater. 2016, 115, 114-124. [CrossRef]

14. Huang, H.; Ye, G.; Qian, C.; Schlangen, E. Self-healing in cementitious materials: Materials, methods and service conditions. Mater. Des. 2016, 92, 499-511. [CrossRef]

15. Van Tittelboom, K.; De Belie, N. Self-healing in cementitious materials-A review. Materials 2013, 6, 2182-2217. [CrossRef] [PubMed]

16. Reinhardt, H.W.; Jooss, M. Permeability and self-healing of cracked concrete as a function of temperature and crack width. Cem. Concr. Res. 2003, 33, 981-985. [CrossRef]

17. Abdel-Jawad, Y.; Dehn, F. Self-Healing of Self-Compacting Concrete; SCC2005: Orlando, FL, USA, 2005; pp. 1023-1029.

18. Granger, S.; Loukili, A.; Pijaudier-Cabot, G.; Chanvillard, G. Experimental characterization of the self-healing of cracks in an ultra-high performance cementitious material: Mechanical tests and acoustic emission analysis. Cem. Concr. Res. 2007, 37, 519-527. [CrossRef]

19. Huang, H.; Ye, G. Simulation of self-healing by further hydration in cementitious materials. Cem. Concr. Compos. 2012, 34, 460-467. [CrossRef]

20. Ahn, T.H.; Kishi, T. Crack self-healing behavior of cementitious composites incorporating various mineral admixtures. J. Adv. Concr. Technol. 2010, 8, 171-186. [CrossRef]

21. Van Tittelboom, K.; Gruyaert, E.; Rahier, H.; Belie, N.D. Influence of mix composition on the extent of autogenous crack healing by continued hydration or calcium carbonate formation. Constr. Build. Mater. 2013, 37, 349-359. [CrossRef] 
22. Termkhajornkit, P.; Nawa, T.; Yamashiro, Y.; Saito, T. Self-healing ability of fly ash-cement systems. Cem. Concr. Compos. 2009, 31, 195-203. [CrossRef]

23. Sisomphon, K.; Copuroglu, O.; Koenders, E.A. Self-healing of surface cracks in mortars with expansive additive and crystalline additive. Cem. Concr. Compos. 2012, 34, 566-574. [CrossRef]

24. Jaroenratanapirom, D.; Sahamitmongkol, R. Self-crack closing ability of mortar with different additives. J. Met. Mater. Miner. 2011, 21, 9-17.

25. Roig-Flores, M.; Moscato, S.; Serna, P.; Ferrara, L. Self-healing capability of concrete with crystalline admixtures in different environments. Constr. Build. Mater. 2015, 86, 1-11. [CrossRef]

26. Azarsa, P.; Gupta, R.; Biparva, A. Assessment of self-healing and durability parameters of concretes incorporating crystalline admixtures and Portland limestone cement. Cem. Concr. Compos. 2019, 99, 17-31. [CrossRef]

27. Sahmaran, M.; Yildirim, G.; Erdem, T.K. Self-healing capability of cementitious composites incorporating different supplementary cementitious materials. Cem. Concr. Compos. 2013, 35, 89-101. [CrossRef]

28. Hung, C.C.; Su, Y.F. Medium-term self-healing evaluation of engineered cementitious composites with varying amounts of fly ash and exposure durations. Constr. Build. Mater. 2016, 118, 194-203. [CrossRef]

29. Şahmaran, M.; Yildirim, G.; Noori, R.; Ozbay, E.; Lachemi, M. Repeatability and pervasiveness of self-healing in engineered cementitious composites. ACI Mater. J. 2015, 112, 513-522.

30. Yıldırım, G.; Khiavi, A.H.; Yeşilmen, S.; Şahmaran, M. Self-healing performance of aged cementitious composites. Cem. Concr. Compos. 2018, 87, 172-186. [CrossRef]

31. Jiang, Z.; Li, W.; Yuan, Z. Influence of mineral additives and environmental conditions on the self-healing capabilities of cementitious materials. Cem. Concr. Compos. 2015, 57, 116-127. [CrossRef]

32. Lefever, G.; Aggelis, D.G.; De Belie, N.; Raes, M.; Hauffman, T.; Van Hemelrijck, D.; Snoeck, D. The Influence of Superabsorbent Polymers and Nanosilica on the Hydration Process and Microstructure of Cementitious Mixtures. Materials 2020, 13 , 5194. [CrossRef] [PubMed]

33. Snoeck, D.; Pel, L.; Belie, N.D. Autogenous Healing in Cementitious Materials with Superabsorbent Polymers Quantified by Means of NMR. Sci. Rep. 2020, 10, 642. [CrossRef] [PubMed]

34. Snoeck, D.; Belie, N.D. Repeated Autogenous Healing in Strain-Hardening Cementitious Composites by Using Superabsorbent Polymers. J. Mater. Civ. Eng. 2016, 28, 04015086. [CrossRef]

35. Snoeck, D.; Tittelboom, K.V.; Steuperaert, S.; Dubruel, P.; Belie, N.D. Self-healing cementitious materials by the combination of microfibres and superabsorbent polymers. J. Intell. Mater. Syst. Struct. 2014, 25, 13-24. [CrossRef]

36. Huang, H.; Ye, G.; Damidot, D. Effect of blast furnace slag on self-healing of microcracks in cementitious materials. Cem. Concr. Res. 2014, 60, 68-82. [CrossRef]

37. Li, G.; Liu, S.; Niu, M.; Liu, Q.; Yang, X.; Deng, M. Effect of granulated blast furnace slag on the self-healing capability of mortar incorporating crystalline admixture. Constr. Build. Mater. 2020, 239, 117818. [CrossRef]

38. Park, B.; Choi, Y.C. Effect of healing products on the self-healing performance of cementitious materials with crystalline admixtures. Constr. Build. Mater. 2021, 270, 121389. [CrossRef]

39. Hemalatha, T.; Ramaswamy, A. A review on fly ash characteristics e towards promoting high volume utilization in developing sustainable concrete. J. Clean. Prod. 2017, 147, 546-559. [CrossRef]

40. Wang, H.Y. The effects of elevated temperature on cement paste containing GGBS. Cem. Concr. Compos. 2008, 30, 992-999. [CrossRef]

41. Jia, Z.; Chen, C.; Shi, J.; Zhang, Y.; Sun, Z.; Zhang, P. The microstructural change of C-S-H at elevated temperature in Portland cement/GGBS blended system. Cem. Concr. Res. 2019, 123, 105773. [CrossRef]

42. Mota, B.; Matschei, T.; Scrivener, K. Impact of $\mathrm{NaOH}$ and $\mathrm{Na}_{2} \mathrm{SO}_{4}$ on the kinetics and microstructural development of white cement hydration. Cem. Concr. Res. 2018, 108, 172-185. [CrossRef]

43. Rodriguez, E.T.; Garbev, K.; Merz, D.; Black, L.; Richardson, I.G. Thermal stability of C-S-H phases and applicability of Richardson and Groves' and Richardson C-(A)-S-H(I) models to synthetic C-S-H. Cem. Concr. Res. 2017, 93, 45-46. [CrossRef]

44. Du, X.; Su, X.; Wang, Y.; Li, J. Thermal decomposition of grinding activated bayerite. Mater. Res. Bull. 2009, 44, 660-665. [CrossRef]

45. Park, B.; Moon, E.J.; Choi, Y.C. Investigation of microstructure and mechanical performance of carbon-capture binder using AOD stainless steel slag. Constr. Build. Mater. 2020, 242, 118174. [CrossRef]

46. Choi, Y.C.; Park, B. Enhanced autogenous healing of ground granulated blast furnace slag blended cements and mortars. J. Mater. Res. Technol. 2019, 8, 3443-3452. [CrossRef]

47. Park, B.; Choi, Y.C. Prediction of self-healing potential of cementitious materials incorporating crystalline admixture by isothermal calorimetry. Int. J. Concr. Struct. Mater. 2019, 13, 36. [CrossRef]

48. Park, B.; Choi, Y.C. Investigating a new method to assess the autogenous healing performance of hardened cement pastes containing supplementary cementitious materials and crystalline admixtures. J. Mater. Res. Technol. 2019, 8, 6058-6073.

49. Qiu, J.; Tan, H.S.; Yang, E.H. Coupled effects of crack width, slag content, and conditioning alkalinity on autogenous healing of engineered cementitious composites. Cem. Concr. Compos. 2016, 73, 203-212. [CrossRef] 